\title{
A Socio-Historical Perspective on Ponzi Schemes and Development in Nigeria: The Role of the Christian Church
}

\author{
Oluwasegun Peter Aluko ${ }^{1, *} \&$ Ibukun Oluwakemi Olawuni ${ }^{2}$ \\ ${ }^{1}$ Department of Religious Studies, Obafemi Awolowo University, Ile-Ife, Nigeria \\ ${ }^{2}$ Department of Christian Religious Studies, Redeemer's University, Ede, Osun State, Nigeria \\ *Correspondence: Department of Religious Studies, Obafemi Awolowo University, Ile-Ife, Nigeria. E-mail: \\ segmoroc@gmail.com
}

Received: May 5, 2021

Accepted: June 8, 2021 Online Published: July 18, 2021

doi:10.5430/wjss.v8n2p41

URL: https://doi.org/10.5430/wjss.v8n2p41

\begin{abstract}
This paper is a study on Ponzi schemes, development and the Christian church in Nigeria. It traced the emergence of Ponzi schemes in Nigeria. The paper considered the practices of Mavrodi Mondial Movement (MMM), being one of the strongest Ponzi schemes in Nigeria. It assessed the impact of this Ponzi scheme on development in the country. It also looked into the role played by the Christian Church during the period of the scheme's existence in the country. The paper, however concluded that, despite the people involved in the scheme being interested in supposedly helping people (including those in the scheme and the less privileged), it is contrary to the ethos of Christianity that touches on labour and its corresponding success. The data collected for the study were analysed using socio-historical approach.
\end{abstract}

Keywords: Ponzi schemes, development, Christianity, Christian Church, MMM

\section{Introduction}

In the era where many people are interested in making quick money or are having the get-rich-quick syndrome, there is nothing they would not do in order to have money and also sustain themselves. Tade (2013) explores the use of Internet fraud popularly known in Nigeria as Yahoo Yahoo and the addition of spiritual elements with internet surfing to boost success rates (Yahoo plus) by the people interested in making quick money. With the addition of spiritual elements, it shows that many people can go to any length in order to get rich. While some are in this act, others resolved to be involved in other acts that are not internet fraud but rather, in investment frauds known as Ponzi schemes. These individuals usually take advantage of the investors on the financial market through fraudulent investment schemes (Amoah, 2018). The fact is, with the collapse of such schemes, the schemers may not be sued as their schemes are often done underground, and because there are no legal frameworks to support those who had lost their investments (see Sadiraj \& Schram, 2018). Even with this, most people are habitually unruffled whenever there is a new scheme in town. The reason is not farfetched as the schemers mostly make use of the happenings around the country to perpetuate their evil schemes. This is why the scheme became very popular in Nigeria during the economic recession of 2016. More recently, there are new Ponzi schemes that are now springing up with the lockdown of the country due to the advent of the novel coronavirus.

On the other hand, development in Nigeria seems to be a fairy tale, as it is becoming unattainable day by day. This is why Ezema and Ogujiuba (2012, p.107) claimed that the Nigerian system has broken down and the economy has failed. The reason for this is because there is gross distortion and inequality in income distribution with the attendant high level of poverty, with Nigeria ranking 160 out of 177 countries with respect to per capita income (Ezema \& Ogujiuba, 2012). A recent report released on January 28, 2020 by the World Bank (2020) showed that the rate of poverty in the country increased from 35.0 to 38.8 per cent of the total population from 2011 to 2016. For a country to be described as developed, the development must include qualitative and quantitative improvement in political, social and economic institutions as well as the distribution of income (Ekong \& Onye, 2012). As Nigerians are grappling with this level of development obscurity in the country, many are still engaging in Ponzi schemes. 
Early in the year 2020, the Security and Exchange Commission (SEC) in Nigeria recently warned stakeholders and the entire public on the activities of promoters of fraudulent schemes in the country (Comms Week, 2020). The Commission even listed the following as some of the unlawful/unlicensed market operators/fraudulent investments that the public must be wary of in 2020 :

- Loom Nigeria Money

- Box Value Trading Company Ltd

- Now-Now Alert

- Flip Cash Investment

- Result Investment Nigeria Limited

- Helping Hand and Investment

- No Failure Development and Empowerment Nigeria Ltd.

- MBA Forex and Investment Ltd

- Federate Investors and Trading Company

- Jamalife Helpers Global Ltd

- Flexus Global Solutions and Investment Ltd

- United Capital Investment Company Limited

Even with this warning and the other warnings that have been given by the Commission in time past, especially during the scourge of the various Ponzi schemes in 2016, many fell and are still falling into the hands of the schemers. What then is the place of the Christian Church in ensuring the safety of those in its constituency?

Studies on Ponzi Schemes have often been examined from different angles of discussion. Some of which have been studied from the economic perspective (Jarvis, 2000; Zuckoff, 2006; Fagan \& Frankel, 2009). Others have looked at it from the judicial aspect (Flaccus, 2006; Schneps \& Colmez 2013; Rapoport, 2012) and from the historical perspective (Bauder, 1985; McDean, 1986; Weisman, 1999; Ponzi, 2001; Frankel, 2012). However, there is a vacuum in such studies as the role of the Christian Church has often been overlooked. Thus, this study intends to fill this gap by probing into the emergence of Ponzi scheme in Nigeria, considering the practices of the scheme in the country. It examines the impact of the scheme on development in the country in line with the Christian Church teachings. Also, it appraises the role played by the Christian church during the period of its existence in the country. As much as there have been many Ponzi schemes in Nigeria, this study will however focus on Mavrodi Mondial Movement (MMM) because of its wide range acceptance and followership by its participants/investors in the country.

\section{Conceptual Clarifications}

\subsection{Ponzi Schemes}

Ponzi schemes are investment frauds that involve payment of purported returns to existing investors from funds contributed by new investors (U.S. Securities and Exchange Commission (SEC) 2019; Greenspan 2011; Wilkins, Acuff and Hermanson 2012). The organisers often solicit new investors by promising to invest funds in opportunities claimed to generate high returns with little or no risk (SEC 2019). This is why Asogwa et al. (2017) opine that this financial investment yielding uncharacteristically high return on investment is based strictly on conscious and serious hunt for admission of new members. Investors cum fraudsters usually focus on attracting new money to make promised payments to earlier-stage investors to create the false appearance that investors are profiting from a legitimate business (What is a Ponzi Scheme, n.d.). More reason Kashi (2017) sees Ponzi scheme as a "mutual aid fund" where ordinary people help each other. But Kashi's definition seems to disrobe the scheme of its fraudulent outlook and shares the views of most Nigerian participants/investors in the scheme. However, to Onoh and Eze (2018), a plotter of anything called Ponzi is nothing except a criminal entrepreneur who seeks to gain the trust of his/her victims through deception.

It should be noted that Ponzi scheme, with little or no legitimate earnings, requires a constant flow of fund by new investors in order to sustain the investment. When there are no new investors, there is surely going to be a vacuum in the flow of fund, which inevitably leads to the collapse of the investment. Since, it is an investment scheme that lures new investors by offering unusually high pay-outs (Olayokun, 2016), there is going to be a collapse when a large 
number of investors ask to cash out. This is well captioned by the Telegraph Reporters (2017) while quoting the United States financial regulator Securities and Exchange Commission that,

Ponzi schemes are a kind of pyramid scheme that operate on the "rob Peter to pay Paul" principle. With the promise of large returns as bait, the fraudster takes in money from new investors and uses it to pay off the earlier investors until no more new recruits can be found and the whole scheme collapses, with the newest investors losing everything.

Historically, though Cohler (2017) believes the real originator of Ponzi scheme is William Miller, dating it back to 1899, generally, the schemes are named after Charles K. Ponzi, who became notorious for using the technique in 1920 in United States of America (Jory and Perry 2014). His claim was to be performing arbitrage with international postal reply coupons (IRC), used to purchase postage stamps. He enticed investors by promising extraordinarily high returns of $50 \%$ in 45 days (Stelter, Berger, Odewald \& Schilder 2013). Instead of using the money to buy the coupons and exchange them for postage stamps, the money of later investors was used to pay returns to earlier investors, thereby extracting huge profits along the way (Jack \& Ibekwe, 2018). With the advent of Mavrodi Mondial Movement (MMM) in Nigeria in November 2015, there had been an astronomical rise in the number of Ponzi schemes in the country with some lasting for a couple of months, while others crash in a couple of days or even hours.

\subsection{Development}

According to Edet (2008), development is a kind of social change during which the well-being and income of the society increases. Some scholars have pondered that not only must wealth be available to society, but also, such increases in wealth must be reflected in average incomes for the families and persons within the society. Ananti and Madubueze (2014) while quoting Rodney, describe development as an increased skill and capacity for greater freedom and creative self-discipline, responsibility and temporal possessions. Though most people usually look at development from the angle of the economy (per capita income), development is more than this. This is why Gotan (2015) believes development in Africa and Nigeria to be precise can be interpreted in two ways: from the purview of underdevelopment, which emphasise material poverty in comparison to developed world economies; and secondly from the viewpoint of Africa being part of the developing world. In case of the former, African underdevelopment reveals that the continent is almost synonymous with poverty, disease, malnutrition, political instability, violence, dependence by corruption and injustice (Gotan, 2015). This shows that for a country to be developed, its development must be encompassing.

\subsection{Christian Church}

With the sociologist, Emile Durkheim defining the church as a moral community (Durkheim, 1965), the Christian Church is the community of believers who link their existence to the activities and the person of Jesus Christ. Its emergence in Nigeria is first traced to the failed attempt it made in the $15^{\text {th }}$ century and the second successful attempt it made in the $19^{\text {th }}$ century through the efforts of Thomas Birch Freeman (representing the Wesleyan Methodist Missionary Society) and Henry Townsend (representing the Church Missionary Society). Ever since the presence of these two missionary societies on the shores of the country exactly in 1842, other Christian missionary societies also came on board. Today, there are numerous Christian churches in the country with many adherents. Ecumenically, the Christian Church in Nigeria is headed by the Christian Association of Nigeria (CAN), which act as the umbrella body and mouthpiece for the Christian adherents in the country.

\section{Review of Related Literature}

Zuckoff (2006) opines that Ponzi scheme involves no legitimate fund investment in assets that can yield any possible income. The money usually paid to the supposed investors are capital contributions from new investors. This means that, this kind of scheme is based on deception, as new investors oftentimes do not know what they are venturing into, except for the high income that must have beclouded their reasoning (cf. DePaulo et al., 1997; Heydenburg, 2015). Once new investors cease from investing, the scheme is bound to collapse. Amoah (2018) states that these schemes come in different shades of investment and business presentations. He avers that,

Some (Ponzi schemes) come in the form of investment companies dealing in financial instrument such as stocks or bonds, investment in foreign currency trading, insurance products, microfinance and banking operations. Others deal with nonfinancial assets, such as real estate, cars, helicopters and funeral insurance products as happened in Lesotho, to any business ideal that can be conceived by the Ponzi operator (Amoah, 2018, p.1116). 
Looking critically at the above view as stated by Amoah, one may tend to believe that Ponzi schemes are legitimate businesses. This is because the involvement of Ponzi operators in any of the investments listed above makes them to have a good source of income that any investor would be proud to associate with. However, this is far from it as anything Ponzi schemes usually promise high returns within a short time. Most of them are often unregistered investments with the Securities and Exchange Commission (SEC), especially in order to deal in any capital market activities. This is why Jack and Ibekwe (2018, p.74) describe the scheme as "an enticing established swindle networking where money of newer entrants or investors are used to pay increased returns to earlier investors rather from profit earned through legitimate business investment." Sadiraj and Schram (2018) even believe that the schemes have typically flourished in countries, where reliable data on variables like inflation or interest rates are difficult to find. This could be said to be true of a country like Nigeria.

Asogwa et al (2017) examine the effect of Ponzi scheme on Nigerian economy during the 2016 economic recession. In their study, the authors discovered that the citizens of the country embraced Ponzi scheme as an alternative for succour during this period. They however state that Ponzi scheme can never serve as a supplement to any harsh economic realities in the country. On their own part, Onoh and Eze (2018) note it was fear and greed that act as the determinant factors for the booming market of anything Ponzi in Nigeria, and never the forces of demand and supply. Kranacher, Riley and Wells (2011) as well see greed as a major factor that contributes to the fraud that is being perpetuated by the schemers and the investors. Both the schemers and the investors are greedy to the extent that the investors often neglect warnings and red flags, all in the hope of very high returns.

However, Greenspan (2009) believes four factors contributed to the success of the Madoff Ponzi scam, and these factors could also be responsible for the success of any other Ponzi schemes in any part of the world. The factors are situation, cognition, personality and emotion. The situation people tend to find themselves usually makes them to fall or be involved in Ponzi scheme. Also, despite people having high intelligence quotient (IQ), it does not mean they cannot be involved in these schemes. This is because people are often looking for easy way out and putting trust in others. On the part of personality, Greenspan opines that the individual disinclination to question a trusted person usually helps a schemer to have success. Moreso, whenever people put emotion into anything, it is believed that this usually becloud their sound judgment into knowing and differentiating what is good from what is bad (Greenspan, 2009).

Cox (2014) calls these schemes "fast money schemes" and views the role being played by the Christian Church in promoting the rise of the schemes in Papua New Guinea. The investors make use of U-Vistract, the largest and most elaborate of the schemes in the country. Cox says that,

U-Vistract had spread through churches, where pastors and church leaders had seen the scheme as a divine blessing. Ordinary investors were required to present a letter from a church minister testifying to their good character, a test that undoubtedly lent U-Vistract an air of credibility. Meetings of the scheme frequently began with prayer, or even interdenominational worship services (Cox, 2014, p.292).

Obviously, the scheme makes use of Christian networks to woo its investors. Even after its collapse, some of the proponents of the scheme still built on investors' acceptance of Christianity and being genuinely born-again before they could be paid any amount of money. This is nothing but what Quisenberry $(2017, \mathrm{p} .2)$ termed as "fraudulent religious leaders acting as wolves and preying on their 'flock' while posing as shepherds." How will being born-again has anything to do with investors being paid their money? This could only be possible when the members who are the investors in this instance have taken the church leaders as their heroes/gods, the only people they believe have access to God. Be that as it may, these studies have created a space that this study intends to fill, by examining the roles being played by the Christian Church in Ponzi schemes and its effect on development in Nigeria.

\section{Theoretical Framework}

This study builds on strain theory as developed by Robert K. Merton (1938). Merton's strain theory describes how crime was triggered by strain, the difference between one's economic goals and his/her actual means of achieving those goals (Merton, 1938). He proposes that when individuals were not capable of meeting their goals through legitimate means they would resort to illegitimate, or illegal measures to achieve their goals (Merton, 1938). While discussing this Merton's strain theory, Carey (2015) stresses that strain is seen as the difference between one's financial goals and one's legitimate means to achieve those goals. In other words, the theory really dwells on the aspect of financial goals of the individual leading to such a person committing fraud. 
According to Mccoy and Pugh (2014), people lacking the resources to financial success often experience strain and it is very important to note that there are different ways people can adjust to this strain. This is the reason Merton (1938, p.676) proposed that conformity, innovation, retreatism, ritualism, and rebellion are the principal ways people can act in response to strain. This theory has been further expanded by different scholars like Cloward and Ohlin (1960), Agnew (1992) and Messner and Rosenfeld (1994).

Though this theory has been criticised over the years for neglecting other forms of crime and dwelling on financial crimes only (See Agnew, 1992), nonetheless, for the benefit of this study, this theory is very relevant. The reason is that the illegal means in this instance is the Ponzi scheme that many are being involved in in order to meet their financial goals in life. Many of the participants/investors really want to "make it big" and it is believed that legitimate means usually take longer time before they could attain this self-imposed belief. These participants/investors are of the view that with Ponzi, they can earn quick money in no mean time, without having to labour and stress themselves.

\section{Method}

The research method followed in this study is qualitative and was carried out in the Obafemi Awolowo University. The Obafemi Awolowo University is a federal university situated in Ile-Ife, Osun State, Nigeria and it admits students from every part of the country. It also has many private workers plying their trade on its premises. The study makes use of both primary and secondary sources of data. The primary data comprises of in-depth interview and participant observation. The interview involved purposively selected thirty (30) respondents, which comprised of twenty (20) ordinary participants/investors and ten (10) guiders who were very active in the MMM scheme. These respondents were majorly Christians in order to ascertain their religious belief in line with their involvement in the scheme. Secondary data were also used and they comprise of relevant literature such as textbooks, journal articles and the Internet. The data collected were analysed using socio-historical analysis.

\section{Brief History of Ponzi Schemes in Nigeria}

The beginning of Ponzi schemes in Nigeria can be traced to the activities of Umana Bank in the 1980s, during the General Ibrahim Babangida's military regime. This bank was owned by Dr Umana E. Umana and was operated in Aggrey Road, Port-Harcourt city (Eziachi, 2012). It operated in such a way that investors could withdraw their money with $100 \%$ interest paid in full after four weeks. This enticed many that they put in into the investment but the aftermath was a total collapse. In 2005/2006, Artmaster, Penny-wise, Trust in God (TIG) Nigeria Ltd. or Treasure Resources Ltd. etc. also came on board with their own wonder working benefits that lured investors. Many also subscribed to them but lost their investments, as they were unable to bring in new investors. These schemes are often seen in the light of wonder banks. In 2006/2007, Nospetco Oil and Gas Limited was also seen as a wonder bank where investors were promised 106\% increase per annum (Olówè, 2006).

From 2015, the Nigeria landscape became agog with the advent of some other schemes promising extraordinary returns on their investments. Schemes like MMM, Icharity, Givers Forum, 247helpers, Zarfund, Twinkas and Ultimate Cycler and so on. All these collapsed and swindled away millions of naira from many of their investors. In 2019, another Ponzi scheme known as Loom came on board and got investors on board. This particular one did not last long before it also crashed. As stated earlier on, many other schemes are now springing up in the year 2020. Nevertheless, since this work is not based on examining all these Ponzi schemes, it will however focus its spectrum on MMM and its practices.

\subsection{MMM}

The name MMM is an acronym that stands for the first letters of the founders' surnames - Sergei Mavrodi, Olga Melnikova and Vyacheslav Mavrodi (Nnamani, 2018). It has variants like Mavrodi Mondial Movement or Mavrodi Mondial Moneybox (See Asogwa et al. 2017; Obamuyi et al. 2018). But for this study, the name Mavrodi Mondial Movement (MMM Nigeria) is used as it is renowned to have been owned by a Russian man named Sergei Mavrodi (b. 11 August, 1955 - d. 26 March, 2018). The scheme started in the year 1989, but however evolved in Nigeria in November 2015 and has many participants/investors on its platform. MMM is not a bank. According to the scheme (mmm-nigeria.net), it claimed not to collect people's money; not an online business, not a high-yield investment programme (HYIP), investment or Multi-Level Marketing (MLM) programme. But in its actual sense, what name could be given to an unregistered investment that promises high returns and uses the investment of new investors to finance that of the old investors if not a Ponzi scheme? The scheme was believed to be a community where people 
help one another, and gave a technical platform which claimed to help millions of its members worldwide to connect those who needed help with those who were willing to provide help, for free. In Nigeria, the scheme had a total number of 3,204,508 members as at $26^{\text {th }}$ June, 2017 (mmm-nigeria.net), just as Obamuyi et al (2018) notes that the scheme had over 2.4 million Nigerians as at late 2016.

MMM is a Ponzi scheme that assured a $30 \%$ return on investment to its participants/investors. This $30 \%$ is just a one-time payment made after thirty days, and not every month payment from one particular profit-yielding investment; although participants/investors can invest as many times as possible after each circle of thirty (30) days. The mode of operation is through the internet and participants/investors made transactions with the local currency (naira) and Bitcoin. When a new participant/investor registered on MMM and referred people to it, even if such an investor was not investing, they earned 10 per cent of the amount the invitee invested (Onyeji, 2016).

On $14^{\text {th }}$ December, 2016, the MMM Nigeria announced the frozen of all accounts but resumed operation on $13^{\text {th }}$ January, 2017. Though some participants/investors had lost hope in the system, others continued not minding their money that had been trapped in the system. It was estimated by the Nigerian Deposit Insurance Scheme (cited by Asogwa et al. 2017) that about 3 million Nigerians lost 18 billion naira (about \$51.5 million USD) to MMM alone sequel to the crash period. Nonetheless, the scheme finally crashed in October, 2017 with many losing millions of naira.

\subsection{The Practices}

It is no news that the practice of Ponzi scheme is fraudulent in nature. However, the existence of MMM in Nigeria brought with it some practices, which were unique to it among other Ponzi schemes in the world. Below are some of these practices:

6.2.1 Trust: Trust is a term that is foremost among every other practice of the scheme. When the participants/investors provided funds (help), it was being done in trust that at the end, they would get their funds back (with interests). They used trust to participate in the scheme. However, it must be noted here that the kind of trust as exhibited by the scheme was one precipitated by the economic conditions of the country (many wanted a quick way out of their penury). In addition, going by the outcome of the scheme in 2017, it was quite glaring that this kind of trust was destined to varnish into thin air when income was not forthcoming.

6.2.2 Provide Help (PH): In this aspect, participants/investors were made to give a specific amount of money, which were often in terms of donation. Such a participant/investor declares the willingness to donate ("Provide Help"), after which his/her account will be rewarded with the same amount he/she has pledged. The money starts increasing (growing, in the language of the participants/investors) from the moment the recipient(s) confirmed the receipt of fund (this increase in funds (called mavros) were usually done on Tuesdays and Thursdays). The sum shows how much investors were able and could request for themselves after a week of making the pledge and paying out to the receiving participant/investor. Participants/investors were usually asked to provide help only with their spare money (even though this is not always the case).

Apart from providing help to themselves, they also formed the habit of charity donations, with a high probability of the participant/investor not knowing the recipient(s) of funds. One thing to really note in this instance is that, this giving is based on the expectation and knowledge that they were going to receive back in multiple folds when they give. This is one aspect of the scheme that made participants/investors to be involved in charity even if such participants/investors were not typical or natural charity maker. Whenever they give, they make a video or picture of it and post it online for more participants/investors to be recruited.

6.2.3 Period of Waiting: After donating cash and being confirmed, the participant/investor is made to wait for a period of two weeks after which the participant/investor would be allowed to get help. This period is often referred to as moratorium/freezing period. One of the respondents who was a banker confessed to not knowing this "moratorium" term prior to the existence of the scheme.

6.2.4 Get Help (GH): Participants/investors are required to get help at the end of thirty (30) days. Such a participant/investor who must have passed through the other processes, may now decide on his/her own accord to "get help" after these days.

6.2.5 Letter of Happiness: MMM must have imbibed the Christian practice of giving testimony, and turned such into writing letter of happiness in order to recruit new participants/investors. It was compulsory for every member to write letter of happiness after they must have been paid their money. Participants/investors were not allowed to continue the scheme without having written the letter of happiness, which would be screened and later published online on the website. 
6.2.6 Guiders: Participants/investors on MMM have guiders, who were people that have been in the system for a while; they were presumed to know the ways the scheme was operated. Whenever the participant/investor encounters a challenge or the other, the first person $\mathrm{s} / \mathrm{he}$ is to meet was the guider. While some guiders were actively involved in rendering services to their downliners (fellow participants/investors who are under them), some were not. Some were just for the profits alone. Thus, the participant/investor could request to change his/her guider if he/she was not satisfied with the guider's services. On MMM platform, there was a place for downliners to rate their guiders.

To be a guider was not compulsory for all participants/investors. There was a school known as Guider's School, which was an online participation school. It was often a tedious one as the would-be guiders were often made to go through rigorous training processes. Most of the time, would-be guiders were unable to make it to the end of the online school. Of course, there were many incentives for guiders and they had information that were not privy to the ordinary participants/investors.

\section{Impact on Development in line with the Christian Church Teachings}

\subsection{Positive Impact}

Bridging ethnic gap: Within the short time of its existence in the country, it could be said that MMM was able to bridge the gap of non-co-existence of different ethnicities. The scheme normally merge persons of different ethnic origin together, not knowing or interested in the participant/investor's ethnic affiliation. In this sense, the Hausas are not telling the Igbos to leave their land and form their own country; rather, they were made to pay money to themselves. However, this kind of co-existence was short-lived as most usually go back to their normal lives after making payments (just the money transaction links them together). Since it was only the issue of money that brought them together in the first instance, and after the money has been paid, received and confirmed, there was no other dealings again. In addition, it was very rare to see that such persons would be paired to pay each other again in any other dealings.

Alternative means of survival: The advent of MMM in Nigeria gave an alternative means whereby most Nigerians, especially the youths could have a means of survival. In the face of harsh economic realities, massive unemployment, high rate of inflation, increase in exchange rate and loss of jobs, many accepted this Ponzi scheme not minding what the aftermath would be. It created a medium for the people to transact business and relate with one another. However, what would be said of this kind of survival that negates the principle of labour? With the way government vehemently spoke against the involvement of its citizens in the scheme, it shows it is a bad scheme that is not suitable for survival. Yes, the economic realities were unfavourable but the survival it gave was one that later on took away happiness from the investors/participants, even in the face of its eventual collapse. Moreso, when an investment of this magnitude is not registered at the appropriate quarters, any kind of survival that comes out of such an investment should be queried and jettisoned, as such is not meant to make people to survive but to give them a short-lived relief.

Economic Relief: Economically, there was money in circulation as many began to "provide and get help". Participants/investors had money to spend on various items as a result of the exchange of money from one person to the other. In addition, commercials banks benefitted from MMM as some people exceed transfer limits of their bank mobile app providing help, and each transfer cost 100 or 105 . This is captioned well by Asogwa et al (2017) when they averred that:

As more people turned to this 'quick fix' system to cushion the effect of the harsh economy resulting primarily from poor living standard caused by skyrocketing inflation, the economy was a little bit reflated. People generally had money to spend through the returns from the Ponzi and the banks were busy with customer either withdrawing their matured investment or initiating new ones through their deposits and transfers.

The above shows that this Ponzi scheme among others actually contributed to the resuscitation of the failing economy of 2016 that led the country into recession. But what about the aftermath of the scheme when it carted away the money of its investors/participants? This, in no small measure, had placed a dent on the economic relief the scheme must have given. More reason Madhavan and Barrass (2011) opine that, "A Ponzi scheme carries the certainty of its own demise... has the potential for its own destruction."

Increase in Mobile Communication: With the means of operation being online, the only avenue for participants/investors to communicate was through the mobile communication. Mobile communication networks enjoyed greatly. Participants/investors made calls and transferred money a lot through the mobile networks. From the 
proceeds of increase in calls to the use of mobile transfer, the mobile networks pay their members of staff. This in turn brings about development.

Giving to the Community: It could be said that MMM had a proclivity to give back to the community. But with the absence of a standard way of generating funds for donation on its platform, it thrived in the area of donating to charity organisations and giving to children. The scheme even partnered a Non-Governmental Organisation (NGO) known as Initiative for Self Esteem Empowerment and Evaluation (ISEE) Inc. in conjunction with Olajumoke Jide Foundation. This partnership was to empower indigent women in Lagos with the sum of $\$ 500,000$ with a view to alleviating poverty (Thisdaylive, 2017). It was a 3-day skills acquisition training that attracted many participants. In the same vein, it donated the sum of one million naira to Jofin Orphanage Home, Jos, Plateau State, for its renovation (The Nation Online, 2017). Below is the compilation of some of the various supports rendered by the participants/investors of MMM on charity basis.

Table 1. Charity Donations by the Participants/Investors of MMM

\begin{tabular}{|c|c|c|c|}
\hline $\mathrm{S} / \mathrm{N}$ & CHARITY DONATION RECIPIENTS & CITY/STATE & DATE \\
\hline 1. & Baptist Hospital & Оуо, Оуо & 21 April, 2016 \\
\hline 2. & Less Privileged & Oke-Anu, Sabo, Lagos & 17 June, 2016 \\
\hline 3. & Havana Children School & Ogudu, Lagos & 23 June, 2016 \\
\hline 4. & $\begin{array}{l}\text { Mercy and Charity Orphanage and Less Privileged } \\
\text { Home }\end{array}$ & $\begin{array}{l}\text { Obosi, Onitsha, } \\
\text { Anambra }\end{array}$ & 26 June, 2016 \\
\hline 5. & Little Saints Orphanage Home & Ogudu, Lagos & 1 July, 2016 \\
\hline 6. & Old Peoples' Home & Minna, Niger & 9 July, 2016 \\
\hline 7. & The Leprosy Centre & Minna, Niger & 15 July, 2016 \\
\hline 8. & Primary Health Care Centre & Kwali, Abuja & 21 July, 2016 \\
\hline 9. & Kwara State Children Centre & Ilorin, Kwara & 23 July, 2016 \\
\hline 10. & Mother of Divine Grace Orphanage & Asaba, Delta & 23 July, 2016 \\
\hline 11. & Asaba Health Centre & Asaba, Delta & 5 August, 2016 \\
\hline 12. & Kwali General Hospital & Kwali, Abuja & 11 August, 2016 \\
\hline 13. & Bosso Maternity Hospital & Bosso, Niger & 13 August, 2016 \\
\hline 14. & Tender Love Orphanage & Awka, Anambra & 21 August, 2016 \\
\hline 15. & The Sick and Weak at Gidan Kwano & Minna, Niger & 22 August, 2016 \\
\hline 16. & Children Reception Centre, Home of the Needy & Ilorin, Kwara & 25 August, 2016 \\
\hline 17. & Edo Orphanage Home & Edo City, Edo & 27 August, 2016 \\
\hline 18. & $\begin{array}{l}\text { Department of Education for the Visually Impaired, } \\
\text { Federal College of Education (Special) }\end{array}$ & Оуо, Оуо & 31 August, 2016 \\
\hline 19. & Abiye Orphanage Home & Osogbo, Osun & 12 September, 2016 \\
\hline 20. & Redeemer's Golden School & Festac Town, Lagos & 28 September, 2016 \\
\hline 21. & $\begin{array}{l}\text { Donated millions to hospital patients in University } \\
\text { College Hospital, Ibadan who are suffering from } \\
\text { deadly ailments and without hope to settle their } \\
\text { hospital bills }\end{array}$ & Ibadan, Oyo & 17 November, 2016 \\
\hline 22. & $\begin{array}{l}\text { Relief materials worth } \$ 5 \text { Million to two Internally } \\
\text { Displaced Persons (IDPs) camps (Gwoza and Bama } \\
\text { IDP Camps located in Durumi area and the New } \\
\text { Kuchingoro IDP camp) }\end{array}$ & FCT, Abuja & 19 November, 2016 \\
\hline 23. & Kingdom Kid Klub Charity & Jos, Plateau & 25 March, 2017 \\
\hline 24. & The Isio Kids Project & Port-Harcourt, Rivers & 22 April, 2017 \\
\hline 25. & F.O.A. Primary School & Lagos & 10 May, 2017 \\
\hline
\end{tabular}

Source: Field Survey, 2017.

These particular charity donations were done by those who had benefitted from the MMM scheme. But as noted earlier on, when the participants/investors give out like this, they make videos of it, upload such videos and are rewarded for it by the scheme. This shows that even as they give, they are still getting back in return. In other words, their giving is being occasioned by what they intend to get back in return. This is very alien to the Christian concept 
of giving.

\subsection{Negative Impact}

Encouraging Laziness: Despite having shades of willingness to be good, the scheme in all ways encourages people to be lazy by the get-rich-quick syndrome. So many unemployed citizens decided to cash in through the scheme and were unable to take up a job, even the lowest job that could have fetched them a token. Even students at various educational levels were not left out.

One of the respondents interviewed notes that:

As I was getting paid through MMM and my income is becoming more than my siblings who were working, I began to feel on top of the world and believed there was no need to even finish my studies as a student.

Another respondent also notes that:

Joining MMM really brought out the laziness in me as I decided to sleep and sleep, knowing that there is going to be income for me once I bring in a new person. I can even GH some amount of money anytime I am broke.

The above show that when one receives money that he/she does not work hard for, there is the probability that such a person may not be willing to be serious with life's duty that could become profitable afterwards. This is in line with the study of Stevens and Weale (2004) on the economic forces determining allocation of time by students between study, paid work and leisure. They found out that lower study time is associated with higher prospective earning. With the collapse of the scheme, what would have become of the laziness in these people? This is why the following biblical verses frowned at laziness, which has been the hallmark of anything Ponzi:

A slack hand causes poverty, but the hand of the diligent makes rich. Proverbs 12:11.

Those who work their land will have abundant food, but those who chase fantasies have no sense. Proverbs 12:24.

Diligent hands will rule, but laziness ends in forced labour. Proverbs 13:4.

A sluggard's appetite is never filled, but the desires of the diligent are fully satisfied. Proverbs 14:23.

Whoever is lazy regarding his work is also a brother to the master of destruction. Proverbs 19:15.

Laziness brings on deep sleep, and the shiftless go hungry. 2 Thessalonians 3:6.

Now we command you, brothers, in the name of our Lord Jesus Christ that you keep away from any brother who is walking in idleness and not in accord with the tradition that you received from us. 1 Corinthians 15:58

Nonetheless, from the observation on the activities of the participants/investors in the scheme in 2016-2017, there were people who were working in different occupations and involved in the scheme. This means they only wanted more sources of income to augment what they were already earning.

Stealing: The end product of anything Ponzi is to technically and tactically steal from the innocent but greedy persons who are mostly new investors/participants. It is no news that many participants/investors lost a large sum of money to the MMM scheme (See Asogwa et al. 2017; Jack \& Ibekwe, 2018; Obamuyi et al. 2018). This means that their money was stolen by the owner(s) of the scheme, which is totally frowned at by the biblical injunction that says: "Thou shalt not steal" (Exodus 20:15). Another injunction says: "For the love of money is the root of all evil: which while some coveted after, they have erred from the faith, and pierced themselves through with many sorrows" (1 Timothy 6:10).

Camouflaged Charity and Humanitarian Services: With the way some of the investors/participants went about helping people, especially the less privileged ones and those in the Internally Displaced Persons (IDPs) camps, people might want to believe this is being done out of freewill and benevolence act. But this is far from the truth. What they do is to give and expect to receive back in multiple folds. Since the scheme also wants this supposed act of benevolence, the investors/participants went about announcing whatever they must have donated to the scheme, for them to be rewarded bountifully. They also used this strategy to woo new investors/participants since the scheme works better with new people who are willing to invest and their money are used to pay off old investors.

Credibility Loss: The people who acted as guiders and those who brought in people, after the collapse of the scheme, these people who must have been held in high esteem would have lost their credibility in one way or the other. An 
example is the one of a branch of the Redeemed Christian Church of God (RCCG) that organised a seminar on it for the members (as would be discussed in the next section). With the eventual breakdown of the scheme, what would have been the lot of the church and the pastor in charge? A biblical injunction says, "A good name is better than great riches" (Proverbs 22:1).

Greed: As many participants/investors began to be paid a 30\% increase in return, the greed in them began to spring up; they continued to put in money in order to receive more returns within a short time. These returns kept the investors interested and many got greedy and did not question how the returns were so high. Since greediness is the excessiveness or inordinate desirous of wealth or profit, many investors seeing the gains from the scheme, continued to invest and even brought in more investors (still with the knowledge of gains from bringing in new investors) till the scheme broke down, scooping all their remaining investments. The Bible has warned against greed: "Then he said to them, 'Watch out! Be on your guard against all kinds of greed; a man's life does not consist in the abundance of his possessions"” (Luke 12:15). One of the respondents notes that:

It was greed that made me to lose all my money in MMM. The profit I realised after I put in some amount of money made me to start inviting my friends to join. I continued to put in money, believing the scheme would never fall. Though I gained some amount of money, but it cannot be compared to the money I lost.

\section{The Role of the Christian Church}

The Christian Church in the country played the following roles:

The Judge/Supporter Role: With the menace that the scourge of this Ponzi scheme (and others) poses, the Christian Church cannot stand aloof, fold its arm or decide to look away. Though the main body of the church in Nigeria - the Christian Association of Nigeria (CAN) never gave an official statement in condemning or supporting it, some churches openly condemned while others surreptitious or openly supported it. Those who supported it believed they were helping their members to move out of poverty by going to the extent of organising seminars on it in the church. One particular instance is a branch of the Redeemed Christian Church of God (RCCG) that organised a seminar on this scheme in the church. Though the National Headquarters of the Redeemed Christian Church of God through her General Secretary, Pastor Johnson Odesola, quickly rose to sternly warn all pastors in her provinces, regions and branches to desist from anything called "get-rich-quick syndrome" (See Opejobi, 2017). Despite this warning, many people have had it in their mind that the church in question had supported the scheme.

Interpreter: Many members of the Christian church battled it out on the sinful or un-sinful nature of the scheme, which made many pastors or leaders of church to make an exposé on it. There were divergent views on whether it is sinful or not. While some church pastors embraced it and even promoted it in their churches to their members, some were indifferent and others really denounced it out rightly, by going to the extent of tagging it "satanic" or "demonic". A prominent pastor who was at the frontline of denouncing the scheme was Apostle Johnson Suleman of the Omega Fire Ministries, who even sacked a pastor for making use of the church's account in participating in the scheme (Augoye, 2017). One of the respondents who was a guider and a leading figure in the church of affiliation notes categorically that there was nothing bad in the scheme as it was an investment that helps people. This shows the respondent does not see anything bad in such a scheme and as such, can continue with the scheme if it did not crash. However, another respondent who was just an ordinary participant/investor in the scheme note that,

MMM was nothing but a fraud and against the ordinances of God as stated in the Bible. I only participated in it because I was seriously in need of money at that particular time and MMM showed up to help out. Though I gained a lot through MMM, but I must confess as a Christian that I know it is not what God wants from we His children.

This shows that even though some of the participants/investors might be knowledgeable about how bad the scheme was, they still got themselves involved in the scheme.

Influencer: Jacobs and Schain (2011) while examining the influential work of Robert Cialdini on how influence and persuasion factors can affect human behaviours, note the following principles:

i. Reciprocation - This is giving in return, an act of returning a favour. In this instance, this behaviour cannot be said to be a factor in the MMM scheme but it could be used in other Ponzi schemes.

ii. Commitment and Consistency - People tend to honour their commitments even after the original motivation to do so is removed. 
iii. Social Proof - People tend to follow the lead of others they trust. This is mostly seen from the way many Christian Church figures used this to lure many of their followers to be involved in the scheme. For example, the sacked pastor of Omega Fire Ministries must have persuaded many of the members into believing the scheme was a good one to alleviate their poverty.

iv. Authority - People tend to obey authority figures even if these figures engage in objectionable acts.

v. Liking - Since individuals they like can persuade people, many of the followers of some Christian Church figures subscribed to the scheme because their followers often like them.

Ike (2007) best captions the influence that the Christian churches have when he notes that:

The power of mobilization of people and the reality of grassroots support and control of the churches over their believers is a factor, which is critical in Nigeria. African peoples believe their religious leaders, and respect the impact of religion on their own personal life and destiny. Not to be religious is to be un-African and indeed un-Nigerian. Christian churches have a potential as social organizations to influence their followers, not just in a prayer or faith encounter but even on social and political matters.

Influence should not be misused by anybody, most especially Church leaders. Most church leaders should not be involved in "robbing Peter to pay Paul." Since they are the mouthpieces of God, they are supposed to be above board.

Encourager: Despite the investors/participants and schemers going against the injunctions of the Bible for hard work, the Christian Church was still open to encourage people to pick up any pieces they must have been left with after the collapse of the scheme. At least, the Christian Church should in their estimation be concerned with the spiritual and social well-being of those within its immediate constituency. This is why Ike (2007) was able to note that, the purpose of the Christian Church is mission for the integral salvation of humankind; it is not just a mission that targets simply the temporal satisfaction and provision of peoples' needs and freedom that is meant. It then shows that the Christian Church is to always act in whatever capacity it found itself to bring succour to its members, even after such may have erred. Just like the prodigal son in the Biblical text, the Christian Church are to always have an open arm to accept whoever is willing to come into the fold of Jesus Christ.

\section{Reflection}

MMM and other Ponzi schemes in Nigeria thrived well because of the economic hardship in the country. Most participants/investors never cared about the risk involved; some were not even interested in the advice of people and the government against venturing into the scheme. No doubt, MMM brought about money to some group of persons, but this cannot actually bring about real development. The reason is not far-fetched: some persons are being rich at the expense of others. As far as development is concerned, this scheme cannot help the people involved, nor will it solve the challenge of recession or economic hardship in the country. If development as earlier on defined by Edet (2008) is anything to go by, then, we can boldly say that Nigeria is not developing in line with the advent of Ponzi schemes in the country. This is because, as some people are working hard to have increase in income legitimately, others are being involved in targeting naïve and often carefree persons to siphon them of their income. Also, since wealth must be available to society and reflect in average incomes for the families and persons within the society, those who have been inadvertently duped of their income via the dubious schemes cannot possess wealth adequately.

The Christian church has a big role to play in making sure their followers are wary of involving themselves in any investment that would cart away their hard-earned income. This is because for real development to take place in the country, the Christian Church must be actively involved with its population in the country. The positive impact the scheme brought were only on the short run, which can never amount to real development per se. In addition, some Christian churches who openly or secretly supported and participated in the scheme gave their members the boldness and courage to be involved, since many of their followers are hero-worshippers who take whatever their pastors say completely. This ought not to be the case.

Apropos, how can anything good come from what is being taken stealthily from other people? This is a very bad investment by people. In short, it is a fraudulent act! Just as the scheme really came to an abrupt end, it shows that the scheme does not have deep root to be able to withstand the socio-economic activities in the country. This may be likened to the seeds that fell on the pathway and on the rocky ground in the Parable of the Sower that was given by Jesus Christ, the progenitor of Christianity. Also, since Ponzi schemes are often unregistered, do not have any 
verifiable address, or a board of directors that run firms that can sue and be sued, they are dubious and should never be trusted. Christianity frowns at this kind of business that is dubious in nature. In addition, the fact that the scheme promised profits without any physical effort except for investors/participants to sit at home, network with their phones/computers and have money in their accounts, there is bound to be stagnation in the flow of the workforce. This is because many of the age grades that are supposed to be working and make sure the society develops are sitting back at home, doing nothing meaningful except to network and money jingles in their accounts.

Needful to say that Ponzi scheme operators will not only promise but also provide what seems to be good returns when the schemes are operating well. However, unbeknown to investors, they are not receiving returns from any investments, but instead are collecting money that was invested by other victims of the Ponzi scheme (Quisenberry, 2017, p.2). This may be likened to the devil giving people what he/she will still have to get back in multiple folds. The earlier the better people got to know that anything that seems to bring in quick and unreasonable returns should be suspected and interrogated before they venture into it.

\section{Conclusion}

What this paper has been able to put forward is the practice of MMM, and how it affected the development of the country, including the roles played by the Christian Church during the period. One thing is sure as noted by Hesselberg (1985), development should denote a complex process of change that may, although not necessarily in the short-run then later, result in improved levels of living for the world's population at large, that is, the collective betterment of humankind. Even though the schemers are often involved in the generosity geared towards charitable organisations and the scheme's interest in "helping people" (including those in the scheme and the less privileged), the scheme is contrary to the ethos of the Christian Church that touches on labour and its corresponding success. It encourages laziness among people, especially the unemployed youths, who see this as an avenue to make it big in life. The Christian Church in all ramifications should discourage such a scheme. Members should be encouraged to do away with cutting corners to reach their goals in life. Also, the government are enjoined to make jobs available for the teeming population of the country.

\section{References}

Agnew, R. S. (1992). Foundation for a general strain theory of crime and delinquency. Criminology, 30(1), 47-83. https://doi.org/10.1111/j.1745-9125.1992.tb01093.x

Amoah, B. (2018). Mr Ponzi with fraud scheme is knocking: Investors who may open. Global Business Review, 19(5), 1115-1128. https://doi.org/10.1177/0972150918788625

Ananti, M. O., \& Madubueze, M. C. (2014). Religion, society, culture and sustainable development in Nigeria: Problems and prospects. Public Policy and Administration Research, 4(11), 34-38.

Asogwa, I. E., Etim, E. O., Imoh, N. E., Akpanuko, E. E., \& Ntiedo, B. E. (2017). Synopsis of Nigerian economy and the growth of Ponzi schemes. Global Journal of Management and Business Research: Economics and Commerce, 17(3), 44-54.

Augoye, J. (2017). Popular Nigerian church sacks pastor for participating in MMM with church's account. Retrieved $13^{\text {th }} \quad$ May, 2020 from https://www.premiumtimesng.com/news/top-news/220756-popular-nigerian-church-sacks-pastor-participatingmmm-churchs-account.html

Bauder, D. C. (1985). Captain money and the golden girl: The J. David affair. San Diego: Harcourt Brace Jovanovich.

Carey, B. (2015). Agnew's general strain theory: Context, synopsis, and application. Interdisciplinary Research \& Analysis, 4, 1-17.

Cloward, R. A., \& Ohlin, L. E. (1960). Delinquency and opportunity: A theory of delinquent gangs. Glencoe, IL: Free Press.

Cohler, A. (2017). The evolution and impacts of the Ponzi scheme and governmental oversight. An Honour's Senior Thesis Project on the Intricacies of Ponzi Schemes and its Regulating Authority, Senior Business Administration Major, Concentration in Finance, Ramapo College of New Jersey, Ramapo College Honour's Symposium, April 12. 
Comms Week. (2020, March 28). SEC lists Ponzi schemes, warns Nigerians. Retrieved $4^{\text {th }}$ July, 2020 from https://www.nigeriacommunicationsweek.com.ng/sec-lists-ponzi-schemes-warns-nigerians/

DePaulo, B. M., Charlton, K., Cooper, H., Lindsay J. J., \& Muhlenbruck, L. (1997). The accuracy-confidence correlation in the detection of deception. Personality \& Social Psychology Review, 1(4), 346-357. https://doi.org/10.1207/s15327957pspr0104_5

Dunn, D. (2004). Ponzi: The incredible true story of the king of financial cons. New York: Broadway.

Durkheim, E. (1965 [1912]). The elementary forms of religious life. Translated and with an Introduction by Karen E. Fields. New York: The Free Press (Simon \& Schuster).

Edet, F. F. (2008). The contribution of religion to national development: A case study of living faith church, a.k.a. winners' chapel. Sophia: An African Journal of Philosophy and Public Affairs, 10(2), 91-97. https://doi.org/10.4314/sophia.v10i2.65089

Ekong, C. N., \& Onye, K. U. (2012). Economic development in Nigeria: The basic needs approach. Munich Personal $\begin{array}{llllll}\text { RePEc Archive } & \text { (MPRA) Paper } & \text { No. 88189. Retrieved from }\end{array}$ https://mpra.ub.uni-muenchen.de/88189/1/MPRA_paper_88189.pdf

Ezema, B. I., \& Ogujiuba, K. (2012). The developmental state debate: Where is Nigeria? Journal of Sustainable Development, 5(1), 100-113. https://doi.org/10.5539/jsd.v5n1p100

Eziachi. (2012). Please where is dr Umana now - Nigerian first 419er? Retrieved 24 $4^{\text {th }}$ June, 2017 from $\mathrm{http} / / / \mathrm{www}$.nairaland.com/964141/please-where-dr-umana-now-nigerian

Fagan, M., \& Frankel, T. (2009). Trust and honesty in the real world: A teaching course in law, business and public policy. Anchorage, AK: Fathom Publishing Company.

Flaccus, G. (2006). Calif man gets 30 years for Ponzi scheme. The Washington Post. Retrieved $25^{\text {th }}$ June, 2017 from http://www.washingtonpost.com/wp-dyn/content/article/2006/05/27/AR2006052700250.html

Frankel, T. (2012). The Ponzi scheme puzzle: A history and analysis of con artists and victims. Oxford: Oxford University Press. https://doi.org/10.1093/acprof:osobl/9780199926619.001.0001

Gotan, C. T. (2015). The status of Nigeria in religion and sustainable development in Africa. Scientific Journal of Pure and Applied Sciences, 4(10), 211-216.

Greenspan, S. (2009). How Bernard Madoff made off with my money or why even an expert on gullibility can get gulled. Skeptic, 14(2), 20-25.

Greenspan, S. (2011). Fooled by Ponzi (and Madoff): How Bernard Madoff made off with my money. Westport, CT: Praeger.

Hesselberg, J. (1985). The Third World in transition: The case of the peasantry in Botswana. Scandinavian Institute of African Studies, Uppsala. $\quad$ Retrieved https://www.diva-portal.org/smash/get/diva2:274394/FULLTEXT01.pdf

Heydenburg, M. R. (2015). The Ponzi scheme as a deception operation: The Bernie Madoff case study. American Intelligence Journal, 32(2), 27-34.

Ike, O. (2007). The Church and civil society: The case of Nigeria. In Church and Civil Society: The Role of Christian Churches in the Emerging Countries of Argentina, Mexico, Nigeria and South Africa, edited by Gerhard Kruip and Helmut Reifeld, pp. 111-126. Sankt Augustin/Berlin: Konrad Adenauer Foundation.

Jack, J. T. C. B., \& Ibekwe, C. C. (2018). Ponzi schemes: An analysis on coping with economic recession in Nigeria. The Nigerian Journal of Sociology and Anthropology, 16(1), 72-90. https://doi.org/10.36108/NJSA/8102/61(0150)

Jacobs, P., \& Schain, L. (2011). The never-ending attraction of the Ponzi scheme. Journal of Comprehensive Research, 9, 40-46.

Jarvis, C. (2000). The rise and fall of Albania's pyramid schemes. Finance \& Development: A Quarterly Magazine of the IMF, 37(1). Retrieved $25^{\text {th }}$ June, 2017 from http://www.imf.org/external/pubs/ft/fandd/2000/03/jarvis.htm

Jory, S. R., \& Perry, M. J. (2014). Ponzi schemes: A critical analysis. Retrieved $21^{\text {st }}$ February, 2020 from https://www.onefpa.org/journal/Pages/Ponzi\%20Schemes\%20A\%20Critical\%20Analysis.aspx

Kashi, V. (2017). List of all Ponzi schemes sites in Nigeria 2017. Retrieved 20 ${ }^{\text {th }}$ February, 2020 from 
https://www.entclass.com.ng/2017/02/ponzi-schemes-sites-list-nigeria.html\#ixzz4y5VaUHGV

Kranacher, M., Riley, R., \& Wells, J. T. (2011). Forensic accounting and fraud examination. Hoboken, NJ: John Wiley \& Sons.

Madhavan, S., \& Barrass, R. (2011). Unsustainable development: Could it be a Ponzi scheme? Surveys and Perspectives Integrating Environment and Society, 4(1), 1-10.

Mccoy, T., \& Pugh, M. (2014). Strain theory. In The Encyclopedia of Criminology and Criminal Justice, First Edition, edited by Jay S. Albanese. John Wiley \& Sons, Inc. https://doi.org/10.1002/9781118517383.wbeccj104

McDean, H. (1986). Captain money and the golden girl: The J. David affair. The Journal of San Diego History, 32(4), 265-267.

Merton, R. K. (1938). Social structure and anomie. American Sociological Review, 3(5), 672-682. https://doi.org/10.2307/2084686

Messner, S. F., \& Rosenfeld, R. (1994). Crime and the American dream. Belmont, CA: Wadworth Publishing Co.

Nnamani, A. (2018). History of MMM in Nigeria. Retrieved 28 ${ }^{\text {th }}$ February, 2020 from https://www.legit.ng/1121339-history-mmm-nigeria.html

Obamuyi, T. M., Iriobe, G. O., Afolabi, T. S., Akinbobola, A. D., Elumaro, A. J., Faloye, B. A., Adeyefa, A. F., Adepoju, T. F., \& Oni, A. O. (2018). Factors influencing Ponzi scheme participation in Nigeria. Advances in Social Sciences Research Journal, 5(5), 429-444. https://doi.org/10.14738/assrj.55.4547

Olayokun, O. (2016, September 12). MMM Nigeria getting stronger, is it a scam or Ponzi. Retrieved $24^{\text {th }}$ June, 2017 from http://www.nigerianarchives.com/2016/09/12/mmm-nigeria-getting-stronger-is-it-a-scam-or-ponzi/

Olówè, A. (2006, December 15). NOSPETCO: A classic Ponzi scheme. Retrieved 24 $4^{\text {th }}$ June, 2017 from http://dejiolowe.com/2006/12/15/nospetco-a-classic-ponzi-scheme/

Onoh, J. O., \& Eze, G. P. (2018). Ponzi schemes in Nigeria - A demographic assessment of attitudes to risk and the role of greed and fear in the market. Journal of Business and African Economy, 4(1), 39-53.

Onoh, J. O., \& Eze, G. P. (2018). Ponzi schemes in Nigeria - A demographic assessment of attitudes to risk and the role of greed and fear in the market. Journal of Business and African Economy, 4(1), 39-53.

Onyeji, E. (2016). 7 trending Ponzi schemes in Nigeria in 2016. Retrieved $4^{\text {th }}$ March, 2020 from https://www.premiumtimesng.com/news/top-news/218130-7-trending-ponzi-schemes-nigeria-2016.html

Opejobi, S. (2017). MMM: Redeemed church warns pastors, members against participating in Ponzi scheme. Retrieved $20^{\text {th }} \quad$ February, 2017 from https://dailypost.ng/2017/01/24/mmm-redeemed-church-warns-pastors-members-participating-ponzi-scheme/

Pearson, N. D., Yang, Z., \& Zhang, Q. (2016). Evidence about bubble mechanisms: Precipitating event, feedback trading, and social contagion. Retrieved 4th July, 2020 from https://intranet.weatherhead.case.edu/document-upload/docs/1402.pdf

Ponzi schemes. (N.d.). Retrieved 24 $4^{\text {th }}$ June, 2017 from https://www.sec.gov/fast-answers/answersponzihtm.html

Ponzi, C. (2001). The rise of Mr. Ponzi. New York, NY: Inkwell.

Quisenberry, W. L. (2017). Ponzi of all ponzis: Critical analysis of the Bernie Madoff scheme. International Journal of Econometrics \& Financial Management, 5(1), 1-6.

Rapoport, N. B. (2012). Black swans, ostriches and Ponzi schemes. Golden Gate University Law Review, 42(4), 627-640.

Sadiraj, K., \& Schram, A. (2018). Inside information in Ponzi schemes. Journal of Economic Science Association, 4, 29-45. https://doi.org/10.1007/s40881-018-0047-4

Schneps, L., \& Colmez, C. (2013). Math on trial: How numbers get used and abused in the courtroom. New York, NY: Basic Books.

Stelter, D., Berger, R., Odewald, J., \& Schilder, D. (2013). Collateral damage: Ending the era of Ponzi finance. Boston: The Boston Consulting Group.

Stevens, P. (2004). Lazy students? A study of student time use. Retrieved 8th July, 2020 from https://www.researchgate.net/publication/5200575_Lazy_Students_A_Study_of_Student_Time_Use 
Tade, O. (2013). A spiritual dimension to cybercrime in Nigeria: The 'yahoo plus' phenomenon. Human Affairs, 23, 689-705. https://doi.org/10.2478/s13374-013-0158-9

Telegraph Reporters. (2017, May 15). Bernard Madoff: What is a Ponzi scheme and how does it work? Retrieved $25^{\text {th }}$ June, 2017 from http://www.telegraph.co.uk/business/0/bernard-madoff-ponzi-scheme-does-work/

The Nation Online. (2017, June 21). MMM Nigeria donates $1 \mathrm{~m}$ to orphanage home in Plateau. Retrieved $25^{\text {th }}$ June, 2017 from http://thenationonlineng.net/mmm-nigeria-donates-n1m-orphanage-home-plateau/

Thisdaylive. (2017, June 23). MMM partners ISEE for women skills acquisition workshop. Retrieved $25^{\text {th }}$ June, 2017 from http://www.thisdaylive.com/index.php/2017/06/23/mmm-partners-isee-for-women-skills-acquisition-workshop/

Weisman, S. L. (1999). Need and greed: The true story of the largest Ponzi scheme in American history. Syracuse, NY: Syracuse University Press.

What is a Ponzi scheme? (N.d.). Retrieved $25^{\text {th }}$ June, 2017 from http://www.mijiki.com/what-is-a-ponzi-scheme.html

Wilkins, A. M., Acuff, W. W., \&. Hermanson, D. R. (2012). Understanding a Ponzi scheme: Victims' perspectives. Journal of Forensic \& Investigative Accounting, 4(1), 1-19.

World Bank. (2020). Nigeria: A short update on poverty and shared prosperity Retrieved 9th July, 2020 from http://documents1.worldbank.org/curated/en/636531549879664295/pdf/NIGERIA-Poverty-Briefing-Note.pdf

Zuckoff, M. (2006). Ponzi's scheme: The true story of a financial legend. New York: Random House.

\section{Copyrights}

Copyright for this article is retained by the author(s), with first publication rights granted to the journal.

This is an open-access article distributed under the terms and conditions of the Creative Commons Attribution license (http://creativecommons.org/licenses/by/4.0/). 